\title{
ENTREPRENEURIAL INTENTIONS: GEM BASED EMPIRICAL ANALYSIS ON THE NORTHERN EUROPE AND ASIAN COUNTRIES
}

\author{
Ambreen Khursheed \\ UCP Business School, Faculty of Management Studies, University of Central Punjab \\ Lahore, Pakistan \\ ambreen.khursheed@ucp.edu.pk \\ Faisal Mustafa \\ UCP Business School, Faculty of Management Studies, University of Central Punjab \\ Lahore, Pakistan \\ faisal.mustafa@ucp.edu.pk \\ Maham Fatima \\ UCP Business School, Faculty of Management Studies, University of Central Punjab \\ Lahore, Pakistan \\ maham.fatima@ucp.edu.pk

\section{Faiza Siddique} \\ UCP Business School, Faculty of Management Studies, University of Central Punjab \\ Lahore, Pakistan \\ faiza.siddique@ucp.edu.pk
}

\begin{abstract}
The requirement to contextualize research in the field of entrepreneurship has converted into the main theme from the last two decades. Therefore, this study bridges the gap by analyzing the relationship between the entrepreneurial activity in northern Europe and the Asian region countries in perspective of an individuals' perception skills, attitudes, and the subjective norms. Based on our research, we propose a new conceptual framework to analyze EI in the context of entrepreneurship by using the theory of planned behavior (TBP) and the Global Entrepreneurship Monitor (GEM). We empirically examine the influence of key developmental differences on the entrepreneurial intentions (EI) model with structural equation modeling (SEM). In the studied GEM countries, our findings affirm the applicability of the EI model across countries confirming that entrepreneurial activities are the key drivers of economic growth. The findings also recommend that the progression from perception to intent is modified across the 23 European and Asian countries, though there exist several cultural differences to the extent of casual effects also including the differences of influential factors. This study contributes to the debate on entrepreneurship by analyzing key factors influencing the EI model and extends our understanding of entrepreneurship.
\end{abstract}

KEYWORDS: entrepreneurial intentions; cultural differences; motivational antecedents; northern Europe; Asian region

JEL CLASSIFICATION: L26, N14, O3

DOI: $10.2478 /$ IJEK-2018-0014

Received: $21^{\text {st }}$ September, 2018

1st Revision: $6^{\text {th }}$ November, 2018

Accepted: $29^{\text {th }}$ November, 2018

Reference: Khursheed, A., Mustafa, F., Fatima, M., Siddique, F. (2018). Entrepreneurial Intentions: Gem Based Emipirical Analysis On The Northern Europe And Asian Countries. International Journal of Entrepreneurial Knowledge, 6(2), 59-70. doi:

10.2478/IJEK-2018-0014 


\section{INTRODUCTION}

Entrepreneurship and its influence on economies are now both widely recognized and determined (Fisher, Maritz, \& Lobo, 2014). In view of the existing benefits of entrepreneurship, policymakers and academicians are highly focused on gaining more understanding of entrepreneurship and its process. The objective of this study is to analyze the entrepreneurial process, considering the factors that influence entrepreneurial intentions (EI), particularly, individual's perception skills, subjective norms, and attitudes. The analysis is based on the dataset of 23 countries falling in Asian and the northern Europe region participating in the Global Entrepreneurship Monitor (GEM) study.

As entrepreneurial intention research is a widespread and emergent research area. The theory of entrepreneurial event reveals the early stages of this research area (Shapero and Sokol, 1982; Shapero, 1984). Later the theory of planned behavior (TPB) was incorporated into EI research, a variety of models have been developed (Bandura, 1982; Ajzen, 1991; Ajzen\&Fishbein, 1980). EI may be considered as the key initial phase in the entrepreneurial activity and venture creation development process. The existing literature provides a variety of entrepreneurship definitions - according to GEM, entrepreneurs are defined as "the adult people who are active in an entrepreneurial way in developing a start-up they will partially own or are owing in the present and running an effective infant business (Reijonen and Komppula, 2007; Hosseini, Dadfar, \&Brege, 2018). In a broader sense, an entrepreneurial experience comprises of creating a new venture (whether workable or not), a small business that provides employment opportunity (Lee \& Wong, 2004). infant and recognized businesses, the establishment of businesses and exits from entrepreneurship.

The entrepreneurial action is unlikely to occur in the absence of EI (Gorgievski, Ascalon, \& Stephan, 2011). Therefore, EI plays a crucial role in getting to understand the whole procedure of entrepreneurship, as EI serves as a base conduit for consequent actions that are associated with organizational development. In view of TPB, there exists three antecedents to EI: subjective norms (SN), personal attitude (PA) and perceived behavioral control (PBC) (Ajzen, 1991; Ajzen, 1988). The main factors leading to real entrepreneurial behavior are various non-influential elements, such as the accessibility of opportunities and financial support (Lumpkin \&Dess 2001). Many studies have determined EI, but from a cross-country point of view, this study fills the research gap. As a research gap is evident in EI studies that would consider regions, though a limited number of countries were examined (Parker, 2004).

The current study fills the research gap by comparing 23 countries falling in the northern Europe and Asian region. These regions are selected for analysis on the basis of their past significant growth in the field of entrepreneurship in comparison to the rest of the European regions and at present they are the most entrepreneurially developed regions to which European Union has paid considerable attention to the application of EU strategy (European Commission, 2010). Historically, all these countries are completely different in view of Global Competitiveness Index and GDP per capita calculated by using purchasing power parity (PPP). In terms of EI and initial entrepreneurial activity levels, they are also different as well as several dimensions are taken into account in the model of this study with the aim to contribute in enhancing the knowledge regarding EI variations in these countries.

Several past studies were commonly based on the research from GEM which is a project which efforts to analyze the association between entrepreneurship and economic development with the help of a research consortium (Reynolds, Bosma, Autio, Hunt, De Bono, Servais, 2005; Bagozzi, Baumgartner \& Yi, 1989). In this study, we also used the GEM database and took a closer look at a conceptual framework developed by relating EI to TBP.

Our study is vital since policymakers and academicians are increasingly focused to encourage more people to start an entrepreneurial career. So far, few empirical studies exist in this field. The objective of this research is bi-fold; to create the applicability of the developed model for doing cross-country 
studies and to analyze the evolving factors and their influence on the entrepreneurial intentions in northern Europe and the Asian region.

\section{LITERATURE REVIEW}

\subsection{Theoretical Framing}

Entrepreneurship researchers agree that entrepreneurial activities vary over time and across countries, and are influenced by various factors (Wach et al. 2016). Commonly EI is defined as an individual's desire to initiate a business or to own someone's business (Bae et al., 2014).

Various models have been applied to explain EI, such as the expected utility model (Douglas \& Shepherd, 2000), Model of executing entrepreneurial ideas (Bird, 1988) and Entrepreneurial Event Model (Shapero, 1984). The early-stage of EI can be found back to the theory of entrepreneurial event (TEE) and to the 1980s (Shapero and Sokol, 1982; Shapero, 1984). According to TEE persistence (inertia) modifies human behavior and the interruption caused by some negative or positive events may lead to displacement in it. The area of EI has further broadened by the joining of TBP from social psychology (Reynolds 1987; Ajzen, 1991; Bandura, 1982; Ajzen, 1988). This theory states that EI highlights the intentions which show a person will be inclined towards a selection of entrepreneurship as a career. In the field of EI, several models have been prepared since then, which applied cognition and perception into entrepreneurial behavior - the conventional entrepreneurial potential model (Gimeno et al. 1997). However, none of them has been as effective as the TBP. Moreover, several studies based on the EI concept have evolved contributing to the latest specifications and applications along with inconsistencies (Cruz et al., 2015).

The eclectic model of entrepreneurship focuses on the abilities and resources of individuals along with their preferences and attitudes towards entrepreneurship as key factors of the social environment that affects entrepreneurship process. As Ajzen highlighted (Ajzen, 1991) that for assessing a particular behavior of interest its antecedents must be analyzed. According to TBP three antecedents describe EI, perceived behavioral control (PBC) describes the apparent difficulty or easiness of doing any kind of entrepreneurial task and the perception regarding the behavioral control. Subjective norm ( $\mathrm{SN}$ ) describes the supposed social pressure or approval to execute or not to execute an entrepreneurial activity. Personal attitude toward entrepreneurship (PA) refers to the extent to which an individual has a satisfactory or disapproving assessment or appraisal of entrepreneurship (Linan\& Chen, 2009). EI has been analyzed in the past empirical studies, and many of them proved that it is influenced by several elements including, PBC, SN and PA (Hayton, George, and Zahra, 2002; Linan and Chen, 2009; Bae et al., 2014; Shinnar, Giacomin\& Janssen, 2012). While many studies also measured intentions differently; some researchers used estimated likelihoods of EI (Kolvereid and Isaksen, 2006) and others used unconditional measures of intentions (Autio et al., 2001). Ajzen (1991) also emphasized that an actual behavior of a person is dependent on various non-motivational factors which comprise of resources and opportunities. Hence, behavioral achievement is dependent on the ability of an individual (behavioral control) and motivation (intention) and this concept are particularly significant in the area of entrepreneurship. In keeping view, the proved significance of TBP this study applies the latest advancements in the TPB.

\subsection{Hypotheses}

In order to assess the antecedents of EI, we connected the intention of individuals with key variables distinguished as antecedent to EI. By considering only, the internal structure of EI along with SN and PBC, the model reveals the influence of PBC and SN on EI. Moreover, our model also includes high job creation (HJC) and perceived opportunities (PO) as constructs that influences one's anticipated barriers and prospects that contributes to EI development. The hypotheses formed for our study are as follows:

H1: Perceived behavioral control influences entrepreneurial intentions.

$\mathrm{H} 2$ : Subjective norms effects entrepreneurial intentions. 
H3: Perceived opportunitiesinfluence perceived behavioral control.

H4: Perceived opportunities influences entrepreneurial intentions.

H5: Expectation of high job creation effects entrepreneurial intentions.

In this study, 23 countries from the Asia and northern Europe are considered. The north European countries are: Lithuania, Estonia, Latvia, Finland, Iceland, Sweden, United Kingdom, Denmark, Ireland, and Norway are located in northern Europe. While from Asia the data of 11 countries was available from the GEM website for the year 2012 and the countries are the China, Iran, Israel, Japan, Malaysia, Pakistan, Palestine, Singapore, South Korea, Taiwan, and Thailand.

In the perspective of economic growth, early-stage entrepreneurial activities are mostly analyzed by the Total Early-Stage Entrepreneurial Activity Rate (TEA), it is the percentage rate of those people whose age fall within the range of 18-64 years and they are either a nascent entrepreneur or an owner-manager of a new start-up (Amoros and Bosma, 2014), wherein a firm's birth is taken as the time when a venture/firm has been disbursing salaries over three months.

Kelley, Bosma and Amorós, (2011) have claimed a significant relationship between economic development and rates of entrepreneurial ventures and also revealed that the level of TEA diminishes with a rise in GDP per capita rise. Thus, GDP of a country allows us to have assumptions for the phase (and type) of early-stage start-ups to be extensive in that country. The GDP per capita of selected countries, TEA with EI rates reported by GEM, Global Competitiveness Index, are shown in Table 1.

Table 1. Total Early Stage Entrepreneurship Prevalence Rate, GDP Per Capita (PPP), and Global Competitiveness Index

\begin{tabular}{|c|c|c|c|c|}
\hline Country & $\begin{array}{c}\text { Global } \\
\text { Competitiveness } \\
\text { Index - overall } \\
2012-2013 \\
\text { (ranks out of 144) Score } \\
(1-7) \\
\end{array}$ & $\begin{array}{l}\text { Entrepreneurial } \\
\text { intention } \\
\text { prevalence rates }\end{array}$ & $\begin{array}{c}\text { Total early-stage } \\
\text { entrepreneurship } \\
\text { prevalence rate } \\
\text { (TEA) }\end{array}$ & $\begin{array}{c}\text { GDP per capita } \\
\text { (PPP) }\end{array}$ \\
\hline \multicolumn{5}{|c|}{ The Northern Europe } \\
\hline Austria & $16(5.22)$ & 8.57 & 9.58 & 0.2224 \\
\hline Denmark & $15(5.27)$ & 6.64 & 5.36 & -0.1499 \\
\hline Estonia & $34(4.64)$ & 16.38 & 14.26 & 4.6812 \\
\hline Finland & $3(5.55)$ & 7.73 & 5.98 & -1.8940 \\
\hline Germany & $6(5.48)$ & 6.01 & 5.34 & 0.3035 \\
\hline Ireland & $27(4.95)$ & 5.43 & 6.15 & -0.3858 \\
\hline Latvia & $55(4.35)$ & 21.85 & 13.39 & 5.3330 \\
\hline Lithuania & $45(4.41)$ & 17.98 & 6.69 & 5.2288 \\
\hline Norway & $28(4.99)$ & 4.91 & 6.75 & 1.3812 \\
\hline Sweden & $4(5.53)$ & 10.96 & 6.44 & -1.0212 \\
\hline UK & $8(5.45)$ & 9.52 & 8.98 & 0.7781 \\
\hline \multicolumn{5}{|c|}{ Asian Countries } \\
\hline China & $29(4.83)$ & 20.39 & 12.83 & 7.3320 \\
\hline Iran & $66(4.22)$ & 22.78 & 10.79 & -8.6091 \\
\hline Israel & $26(5.02)$ & 12.81 & 6.53 & 0.0777 \\
\hline Japan & $10(5.40)$ & 2.49 & 3.99 & 1.6573 \\
\hline Malaysia & $25(5.06)$ & 13.34 & 6.99 & 3.5371 \\
\hline Pakistan & $124(3.52)$ & 24.51 & 11.57 & 1.3385 \\
\hline Palestine & $22(4.01)$ & 35.61 & 9.84 & 1.0213 \\
\hline Singapore & $2(5.67)$ & 16.08 & 11.56 & 1.5607 \\
\hline South Korea & $19(5.12)$ & 12.98 & 6.64 & 1.7560 \\
\hline Taiwan & $13(5.28)$ & 25.49 & 7.54 & 1.9541 \\
\hline Thailand & $45(4.89)$ & 18.98 & 18.94 & 6.7466 \\
\hline Turkey & $43(4.45)$ & 14.72 & 12.22 & 3.1592 \\
\hline
\end{tabular}

Source: World Bank, International Comparison Program database: GDP per capita based on purchasing power parity (PPP) (current US dollar-2017).

Source Global Competitiveness report 2012 
Source: Global Entrepreneurship Monitor (GEM-2012), Adult Population Surveys.

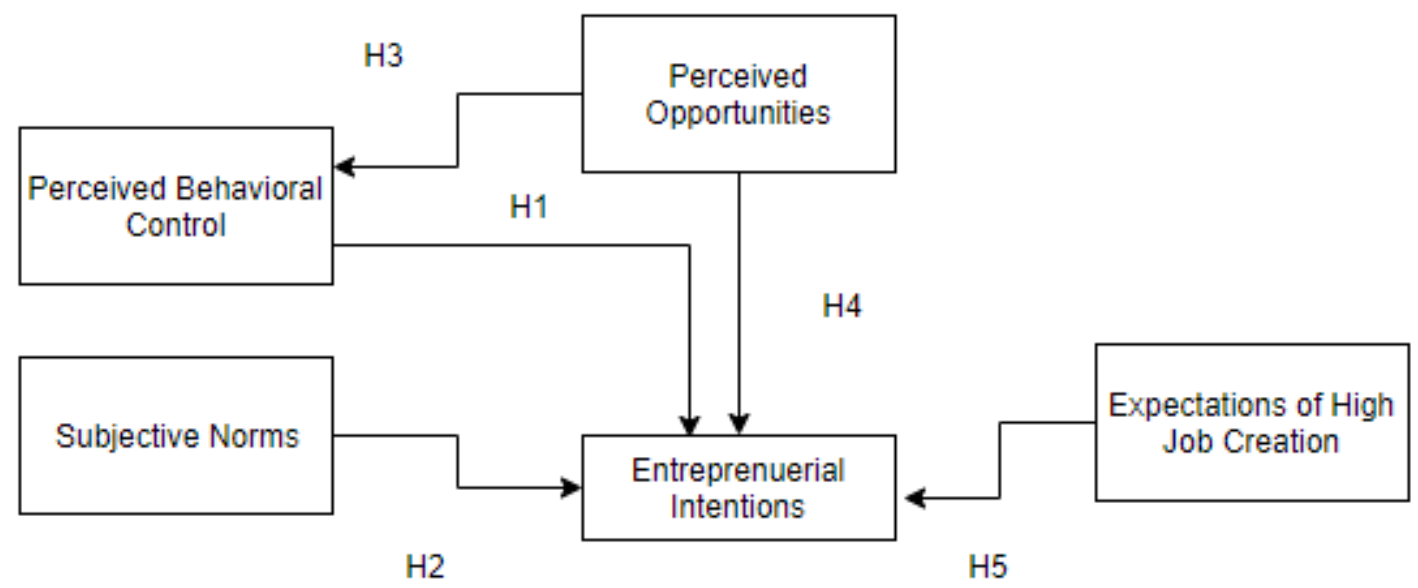

Figure 1: Conceptual Framework

\section{METHODOLOGY}

The study analysis representative samples of adult people from 23 countries selected from northern Europe and Asia region with GEM research. GEM reports of 2012 have been considered as the main source of data regarding entrepreneurial activities and attitudes towards start-ups. The construct taken in this study along with their respective measurements are explained as follows:

\section{Perceived Opportunities (PO)}

This variable measures the percentage of those people who recognize best opportunities in the market for launching their entrepreneurial venture. Their age range is from 18 to 64 years. This variable is measured as a binary variable by assigning $1=$ individual perceiving opportunities, $0=$ individual not perceiving opportunities.

\section{High Job Creation (HJC)}

High job creation measures the percentage of those people who are at the early stage of entrepreneurship and expect to create job opportunities comprising of minimum 6 or more jobs within the next five years. Its measure is done by using a binary variable by assigning $0=$ No and $1=$ Yes.

In accordance to theory of planned behavior, the entrepreneurial intentions of a person are recognized through the attitude towards a certain phenomenon, like subjective norms and perceived behavioral control. By considering this aspect, in this paper we have included perceived behavioral control by including two factors;

\section{- $\quad$ Fear of Failure (FF)}

This variable assesses the percentage of people falling within the age range of 18 to 64 years perceiving prospects in the field of entrepreneurship but expresses that fear of failure may prevent them from launching their entrepreneurial venture.

\section{- $\quad$ Perceived Capability (PC)}

This variable evaluates the percentage of those people falling within the age range of 18 to 64 years who know that they have the required abilities and understandingto launch their entrepreneurial venture. Both elements were evaluated using binary variables $(1=$ Yes, $0=$ No)

\section{Entrepreneurial Intentions (EI)}


In this study we have analyzed EI as the dependent variable. For the application of our methodology we have measured this variable as a twofold factor: a person is assigned $1 \mathrm{if} \mathrm{h/she} \mathrm{plans} \mathrm{to} \mathrm{launch} \mathrm{their} \mathrm{own} \mathrm{business} \mathrm{in}$ the upcoming three years, 0 in the other case.

\section{EI (Antecedents)}

In view of existing literature, $\mathrm{PBC}$ and $\mathrm{SN}$ are considered as the antecedents of entrepreneurial intentions. In this study, PBC and SN impact on EI are measured by using following two elements;

- Innovation:

This variable involves the percentage of those people who are at the early stage of entrepreneurship and expresses that their product or service is novel to at least some consumersand few or no venture is producing the same product or service $(1=$ Yes, $0=$ No).

- Entrepreneurial Employee Activity (EEA):

This variable measures the rate of participation of employees in activities related to entrepreneurship, like producing new product or service etc. $1=$ Yes, $0=$ No).

\subsection{Sample Description}

The selected data were collected from the 2012 Global Entrepreneurship Monitor research website.

Table 2 shows that all the variables of the study have Cronbach alpha values greater than 0.6 which confirms the internal consistency of constructs on reliability scale. The characteristics of European and Asian countries selected as sample for our study are exhibited in Table 3.

Table 2 Constructs' Reliability

\begin{tabular}{rlc}
\hline Serial No. & Variables & Cronbach's Alpha \\
\hline 1 & Perceived Opportunities & 0.820 \\
2 & High Job Creation & 0.910 \\
3 & Fear of Failure & 0.904 \\
4 & Perceived Capabilities & 0.958 \\
5 & Innovation & 0.905 \\
6 & Entrepreneurial Employee Activity & 0.812 \\
7 & Entrepreneurial intentions & 0.885 \\
8 & Average Cronbach Alpha & $\mathbf{0 . 8 8 4}$ \\
\hline
\end{tabular}

Table 3 Characteristics of the European countries

\begin{tabular}{|c|c|c|c|c|}
\hline Country & Sample size & $\begin{array}{l}\text { Number of males } \\
\text { in the sample }\end{array}$ & $\begin{array}{l}\text { Number of } \\
\text { females in the } \\
\text { sample }\end{array}$ & $\begin{array}{l}\text { Average age, } \\
\text { in years }\end{array}$ \\
\hline \multicolumn{5}{|c|}{ Subsample 1 (Northern Europe) } \\
\hline Austria & 4570 & 2,259 & 2,311 & 42.57 \\
\hline Denmark & 5549 & 3,115 & 2,434 & 43.05 \\
\hline Estonia & 4247 & 2,109 & 2,138 & 38.52 \\
\hline Finland & 1001 & 489 & 512 & 40.51 \\
\hline Germany & 1551 & 882 & 669 & 43.52 \\
\hline Ireland & 2536 & 1,121 & 1,415 & 40.57 \\
\hline Latvia & 2830 & 1,317 & 1,513 & 42.87 \\
\hline Lithuania & 822 & 431 & 391 & 40.61 \\
\hline Norway & 963 & 460 & 503 & 41.51 \\
\hline Sweden & 2298 & 1,118 & 1,180 & 40.52 \\
\hline $\mathrm{UK}$ & 5,733 & 2,821 & 2,912 & 39.50 \\
\hline \multicolumn{5}{|c|}{ Subsample 2 (Asian Countries) } \\
\hline China & 1984 & 1,012 & 972 & 41.53 \\
\hline Iran & 8898 & 3,274 & 5,624 & 42.89 \\
\hline Israel & 2705 & 1,213 & 1,492 & 43.52 \\
\hline Japan & 2294 & 1,354 & 940 & 42.89 \\
\hline Malaysia & 1987 & 916 & 1,071 & 40.78 \\
\hline Pakistan & 2618 & 1,453 & 1,165 & 39.20 \\
\hline
\end{tabular}




\begin{tabular}{lllll}
\hline Palestine & 4578 & 2,231 & 2,347 & 41.51 \\
Singapore & 3066 & 1,545 & 1,521 & 41.09 \\
South Korea & 1539 & 654 & 885 & 40.58 \\
Taiwan & 4683 & 2,219 & 2,464 & 41.10 \\
Thailand & 3,094 & 1,437 & 1,657 & 41.39 \\
Turkey & 4,402 & 2,631 & 1,771 & 39.51 \\
\hline
\end{tabular}

Source: Adult Population Survey - Global Entrepreneurship Monitor (GEM)

Table 4 Total Country Measures

\begin{tabular}{|c|c|c|c|c|c|c|}
\hline Country & $\begin{array}{l}\text { Entrepreneurial } \\
\text { Employee } \\
\text { Activity }\end{array}$ & $\begin{array}{l}\text { Perceived } \\
\text { Capabilities }\end{array}$ & $\begin{array}{l}\text { Perceived } \\
\text { Opportunities }\end{array}$ & $\begin{array}{l}\text { Fear of } \\
\text { Failure }\end{array}$ & Innovation & $\begin{array}{l}\text { High Job Creation } \\
\text { Expectations }\end{array}$ \\
\hline \multicolumn{7}{|c|}{ Subsample 1} \\
\hline Austria & 11.01 & 49.61 & 49.21 & 35.96 & 33.55 & 10.14 \\
\hline Denmark & 12.62 & 31.02 & 44.41 & 39.26 & 44.41 & 25.72 \\
\hline Germany & 10.05 & 37.09 & 36.16 & 41.91 & 31.77 & 23.1 \\
\hline Ireland & 12.60 & 45.16 & 25.55 & 35.37 & 37.33 & 31.45 \\
\hline Latvia & 10.81 & 43.56 & 33.05 & 36.74 & 34.59 & 48.43 \\
\hline Sweden & 11.58 & 36.99 & 66.48 & 32.61 & 21.15 & 15.72 \\
\hline United & 10.08 & 47.13 & 32.82 & 36.01 & 30.54 & 23.66 \\
\hline Kingdom & & & & & & \\
\hline \multicolumn{7}{|c|}{ Subsample 2} \\
\hline China & 0.59 & 37.6 & 32.24 & 35.82 & 21.06 & 18.23 \\
\hline Iran & 0.74 & 54.15 & 39.17 & 41.42 & 7.95 & 16.42 \\
\hline Israel & 4.24 & 29.31 & 30.62 & 46.76 & 29.15 & 21.33 \\
\hline Japan & 3.01 & 9 & 6.37 & 53.13 & 21.73 & 32.03 \\
\hline Malaysia & 0.9 & 30.82 & 35.69 & 36.34 & 17.13 & 12.82 \\
\hline Pakistan & 0.17 & 48.74 & 46.48 & 31.24 & 28.49 & 22.77 \\
\hline Palestine & 2.46 & 59.37 & 46.14 & 40.19 & 21.48 & 25.61 \\
\hline Singapore & 2.86 & 26.58 & 22.51 & 41.63 & 21.79 & 39.63 \\
\hline South & 2.07 & 26.93 & 12.52 & 43.01 & 26.53 & 29.44 \\
\hline \multicolumn{7}{|l|}{ Korea } \\
\hline Taiwan & 3.78 & 26.38 & 38.55 & 37.6 & 18.85 & 37.77 \\
\hline Thailand & 1.11 & 45.97 & 44.61 & 50.06 & 19.57 & 12.15 \\
\hline Turkey & 0.97 & 49.44 & 39.88 & 30.39 & 24.89 & 36.56 \\
\hline
\end{tabular}

Source: Adult Population Survey - Global Entrepreneurship Monitor (GEM)

Table 4 reveals total country measures of the selected factors assessed in this study. For assessing the data structural equation modeling (SEM) technique is used as it assesses to analyze the relationships between mulitiple independent and dependent constructs (Henseler, J., and Sarstedt, M. 2013; Brewer, Cinner, Fisher \& Wilson, 2012). In order to assess the goodness fit of our model, we have applied tests of goodness fit (GoF), average adjusted R-square (AARS) and average path coefficient (APC). Similarly, path coefficients are used for testing hypothesis, level of significance $(\mathrm{p}<0.01,0.05,010)$ and standard error. For analyzing the subsets of countries parametric t-tests are used.

\section{RESULTS AND DISCUSSION}

According to the results, majority of the paths are found significant while few were found non-significant. The results revealed that the relationship between perceived capabilities is positive and significant while the relationship between fear of failure over intentions is negative but insignificant and this result is in contrast to the past studies (Corbett, 2007; Cassar\& Friedman, 2009). This result may lead to future direction for more comprehensive research on these factors. The result proves that if a person is having strong abilities then he/she would have greaterentrepreneurial intentions and this result is aligned with past research studies (Conroy 2004; Bosma et al., 2008). Thus, H1 of our study is partly accepted.

Table 5 Path Coefficients (Estimated Values)

\begin{tabular}{llllll}
\hline Hypotheses & Model group 1 & $\begin{array}{l}\text { Path } \\
\text { coefficient }\end{array}$ & $\begin{array}{l}\text { Expected } \\
\text { relationship }\end{array}$ & $\begin{array}{l}\text { Standard } \\
\text { error }\end{array}$ & $\begin{array}{l}\text { Significance } \\
\text { level }\end{array}$ \\
\hline $\mathrm{H} 1 \mathrm{PC} \rightarrow$ intention & $0.411^{* * *}$ & Positive & 1.69 & Significant \\
\hline
\end{tabular}




\begin{tabular}{llllll}
\hline & FF $\rightarrow$ intention & -0.055 & Negative & -0.007 & Non-significant \\
H2 & innovation $\rightarrow$ intention & $0.016^{*}$ & Positive & 1.78 & Significant \\
& EEA $\rightarrow$ intention & $0.068^{* *}$ & Positive & 0.034 & Significant \\
H3 & innovation $\rightarrow$ capability & $0.044^{* *}$ & Positive & 0.021 & Significant \\
& EEA $\rightarrow$ capability & $0.152^{* * *}$ & Positive & 0.086 & Significant \\
H4 & PO $\rightarrow$ capability & $0.144^{* *}$ & Positive & 0.072 & Significant \\
& PO $\rightarrow$ fear & $-0.203^{*}$ & Negative & -0.076 & Significant \\
H5 & $\mathrm{HJC} \rightarrow$ intention & $0.015^{*}$ & Positive & 5.576 & Significant \\
\hline
\end{tabular}

Note: $*$ indicates significant level at $1 \%, * *$ indicates significant level at $5 \%, * * *$ significant level at $10 \%$ Values of AARS $=0.072, \mathrm{p}<0.05 ; \mathrm{GoF}=0.212 ; \mathrm{APC}=0.082$

Table 6 Path Coefficients (Northern Europe \& Asian Countries)

\begin{tabular}{|c|c|c|c|c|c|}
\hline Hypotheses & Model group 1 & $\begin{array}{l}\text { Path } \\
\text { coefficient } \\
\text { (Northern } \\
\text { Europe) }\end{array}$ & $\begin{array}{l}\text { Path } \\
\text { coefficient } \\
\text { (Asia) }\end{array}$ & $\begin{array}{l}\text { Expected } \\
\text { relationship }\end{array}$ & $\begin{array}{l}\text { Significance } \\
\text { level }\end{array}$ \\
\hline \multirow[t]{2}{*}{ H1 } & $\mathrm{PC} \rightarrow$ intention & $\begin{array}{l}0.231^{* * *} \\
(0.129)\end{array}$ & $\begin{array}{l}0.115^{* *} \\
(0.050)\end{array}$ & Positive & Significant \\
\hline & $\mathrm{FF} \rightarrow$ intention & $\begin{array}{l}-0.045 \\
(0.031)\end{array}$ & $\begin{array}{l}-0.025 \\
(0.025)\end{array}$ & Negative & Non-significant \\
\hline \multirow[t]{2}{*}{$\mathrm{H} 2$} & innovation $\rightarrow$ intention & $\begin{array}{l}0.024^{* *} \\
(0.0125)\end{array}$ & $\begin{array}{l}0.036^{* * *} \\
(0.020)\end{array}$ & Positive & Significant \\
\hline & $\mathrm{EEA} \rightarrow$ intention & $\begin{array}{l}0.078^{*} \\
(0.0310)\end{array}$ & $\begin{array}{l}0.069^{*} \\
(0.026)\end{array}$ & Positive & Significant \\
\hline \multirow[t]{2}{*}{$\mathrm{H} 3$} & innovation $\rightarrow$ capability & $\begin{array}{l}0.054^{* * *} \\
(0.030)\end{array}$ & $\begin{array}{l}0.047^{* * *} \\
(0.025)\end{array}$ & Positive & Significant \\
\hline & EEA $\rightarrow$ capability & $\begin{array}{l}0.162^{*} \\
(0.057)\end{array}$ & $\begin{array}{l}0.145^{* * *} \\
(0.084)\end{array}$ & Positive & Significant \\
\hline \multirow[t]{2}{*}{$\mathrm{H} 4$} & PO $\rightarrow$ capability & $\begin{array}{l}0.176^{* *} \\
(0.081)\end{array}$ & $\begin{array}{l}0.185^{* *} \\
(0.92)\end{array}$ & Positive & Significant \\
\hline & PO $\rightarrow$ fear & $\begin{array}{l}-0.124^{* *} \\
(-0.063)\end{array}$ & $\begin{array}{l}-0.194^{* * *} \\
(0.106)\end{array}$ & Negative & Significant \\
\hline H5 & $\mathrm{HJC} \rightarrow$ intention & $\begin{array}{l}0.052^{* * *} \\
(0.027)\end{array}$ & $\begin{array}{l}0.069^{* * *} \\
(0.038)\end{array}$ & Positive & Significant \\
\hline
\end{tabular}

Note: * indicates significant level at 1\%, **indicates significant level at 5\%, *** significant level at $10 \%$ Values of AARS $=0.085, \mathrm{p}<0.05 ; \mathrm{GoF}=0.292 ; \mathrm{APC}=0.078$

In order to assess the influence of subjective norms over entrepreneurial intentions, the impact of innovation on intentions and entrepreneurial activity on intentions is considered. Our results regarding the influence of innovation on intentions reveals that innovations positively influences intentions and this finding is consistent with past studies which found that innovation is an aptitude to recognized opportunities and use them in innovative ways and it enhances intentions (Robinson et al., 1991; Schumpeter, 1934).Regarding the influence of entrepreneurial activity on intentions we found a positive relationship between the both. The findings prove that employees participating more in entrepreneurship field would have higher EI andthis is also consistent with past studies (Kuratko, 2005; Lado\&Vozikis, 1996). Thus, H2 is proved.PBC is the perceived easiness or difficulty of exhibiting a behavior under different circumstances when the behavior may go out of controllable situations of forecasting behavior directly or indirectly. For assessing the influence of perceived opportunities on $\mathrm{PBC}$, we assessed the impact of innovation and entrepreneurial employee activity (EEA) on intentions.

Our results reveal that innovation and entrepreneurial employee activity positively and significantly influences perceived capability. Therefore, our findings confirm that people perceiving their product or service is novelin the market to at least few customers would have positive perception regarding their abilities of starting their own venture and similarly entrepreneurial activities boosts positive perception regarding own capabilities of an individual and this result is also supported by past studies (Kuratko, 2005; Hamidi et al., 2008).Our results indicate that an individual having strong potential of recognizing opportunities in the market would have stronger control over his behavior and would have higher entrepreneurial intentions. This finding is consistent with past studies indicating positive relationship between both the constructs (Ajzen, 1991; Ajzen\& Madden, 1986). Hence, H3 and H4 is proved. 
Recent research recommends that the number of entrepreneurs who expect to create maximum number of jobs, leads to higher macro-economic growth and to entrepreneurial intentions in general (Stam, Suddle, Hessels, \& Van Stel, 2009; Stam, Hartog, Van Stel, \&Thurik, 2011;). Our results also show that entrepreneurs expecting to create job opportunities would have stronger EI and the result supports $\mathrm{H} 5$.

\section{CONCLUSION}

A realization of personal effectiveness that is both strong and accurate is critical to the commencement and tenacity of performance in all phases of human progress (Lent \& Hackett, 1987). The most valuable contribution of our study is that the EI model is appropriate to apply across different countries and the antecedents of EI have a statistically significant effect on EI. This article's approach is fundamentally validated as it gives outcomes that are consistent with the modified conceptual framework. Hence, this study represents a key step toward recognizing entrepreneurship in a more systematic way from a career viewpoint and considering mainly the entrepreneurial context. The study further exposed that the impact of PBC and SN factors are stable and significant across all countries. The findings are supported by the literature which indicated that PBC and SN are extremely important in determining EI (Wedayanti, N. P., \&Giantari, I., 2016; Cruz et al., 2015). This study also recommends that the extent to innovation level have a significant and positive impact on EI. As, TPB describes that individuals are concerned about theirperceptionsregarding their own abilities and capabilities (Krueger et al., 2000; Ajzen, 1991). Additionally, these findings support prior studies that associated perceived the capability to entrepreneurship (Bandura, 1982; Krueger, Reilly and Carsrud, 2000; Martinez, M., Yang, T. \& Aldrich, H., 2011). As perceiving entrepreneurship, a creator of job opportunities also has a significant and positive influence on EI. With the help of structural equation modeling the internal structure of selected antecedents of EI is analyzed in which the key role of perceived opportunities and entrepreneurship employee activity (EEA) are also supported by the key results of the study which depicted a positive and significant relationship with intent and this is also consistent with past studies that indicated the importance of perceived opportunities of an entrepreneur with the key actors of entrepreneurial ecosystem leads to undertaking of successful entrepreneurial career (Bruton et al., 2013; Clemens, 2006).

From a practical perspective of the strategic priorities of north European countries and the Asian region, various policy implications can be recommended. By considering the viewpoint of entrepreneurial perceived opportunities and perceived capabilities, it is essential to associate a variety of formal and informal entrepreneurial learning methods and training techniques, which focuses on teamwork in an actual entrepreneurial ecosystem. Policy measures should be focused on boosting entrepreneurial knowledge, capabilities and reducing the fear of failure as it affects key factors leading to influence the decision of an entrepreneur.

Though many past researchers have analyzed entrepreneurial intentions from a cross-cultural viewpoint (Davidsson, 1995; Hayton, George, \& Zahra, 2002; Davidsson\&Wiklund, 1997). Our research contributes by providing a valuable knowledge of how key variations across countries modify entrepreneurial intentions along with their antecedents in the countries of northern Europe and the Asian region. In this study, we did not limit this study to institutional factors, but we focused on the European and Asian countries with its key features, affecting the link of a probability of reporting entrepreneurial intentions with its antecedents, making this study commendable in the future.

This study supplements past studies and makes contributions to the research in the following ways. First, in view of analyzing GEM data, it uses the Adult Population Survey (APS) data that strives to compare entrepreneurial activities by collecting the most reliable and latest data from all countries. Second, the study combines the entrepreneurial intention components with the theory of planned behavior (TPB) and formulated a GEM-based conceptual framework and highlighted the role of EI in an entrepreneurial context. Finally, the study tests the applicability of the developed framework across entrepreneurially developed in 23 European and Asian 
countries. Findings of this study also disclose that policymakers should know that entrepreneurial activity is not only dependent on an individuals' amateur liking of entrepreneurial career and its challenges, but it is also dependent on the conditions provided for starting an entrepreneurial venture. Thus, the environment plays a key role in enhancing entrepreneurial activity in any country. Based on our findings, we suggest that the north European and the Asian region countries' have stronger entrepreneurial intentions rooted in their feelings linked to their capability to perform in the field of entrepreneurship, mirroring outcomes found in the SEM analysis confirms that perceived abilities are significantly linked to intentions. In spite of the key empirical and conceptual contributions of our study, our findings also provide several recommendations for the entrepreneurship policy makers so that they may foster entrepreneurship initiatives at a national level in the European context of 2020 Strategy.

Concerning the findings of this research, three limitations should be noted, each of which leads to future research. First, this study analysis EI within a reasonably narrow timeframe as it is a cross-sectional study. Mainly, EI is not stable over time in view of dynamic economic conditions. As such, it would be interesting to follow our study in a longitudinal timeframe in order to analyze the evolution of EI over time. Secondly, it would be of interest to investigate the extent to which EI results in the creation of new entrepreneurial ventures and after that, the key factors can be identified. Third, in order to determine the authors and pivotal research work of this field, we suggest a co-citation investigation on the same research subject.

\section{REFERENCES}

Ajzen, I. (2001). Nature and operation of attitudes. Annual Review of Psychology, 52, 27-58. http://dx.doi.org/10.1146/annurev.psych.52.1.27

Ajzen, Icek and Martin Fishbein. (1980). Understanding attitudes and predicting social behavior, Englewood Cliffs, NJ: Prentice Hall.

Ajzen, Icek, \& Madden, T. J. (1986). Prediction of goal-directed behavior: Attitudes, intentions, and perceived behavioral control. Journal of Experimental Social Psychology, 22(5), 453-474.

Ajzen, Icek. (1988). Attitudes, personality, and behavior, milton-keynes: Open University Press and Chicago, IL: Dorsey Press.

Ajzen, Icek. (1991). The theory of planned behavior, Organizational Behavior and Human Decision Processes, 50,179-211. https://doi.org/10.1016/0749-5978(91)90020-T

Amoros, Jose Ernesto and Niels Bosma. (2014). GEM, 2013 Global Report, Babson Park, MA and Santiago, Chile: Babson College and Universidad del Desarrollo.

Autio, Erkko, Robert H. Keeley, Magnus Klofsten, George G. C. Parker and Michael Hay. (2001). Entrepreneurial intent among students in scandinavia and in the USA, Enterprise and Innovation Management Studies, 2(2), 145-160 https://doi.org/10.1080/14632440110094632

Bae, Tae Jun, Shanshan Qian, Chao Miao and James O. Fiet. (2014). The relationship between entrepreneurship education and EI: A Meta-Analytic Review, Entrepreneurship Theory and Practice, 38(2), 217-254. https://doi. org/10.1111/etap.12095

Bagozzi, R.P., Baumgartner, J., \& Yi, Y. (1989). An investigation into the role of intentions as mediators of the attitude-behaviour relationship. Journal of Economic Psychology, 10(1), 35-62.

Bandura, Albert. (1982). The assessment and predictive generality of self-percepts of efficacy, Journal of Behavior Therapy and Experimental Psychiatry, 13(3), 195-199. https://doi.org/10.1016/00057916(82)90004-0

Bird. B. (1988). Implementing entrepreneurial ideas: The case for intention. Academy of Management Review. 1(3), 442-453.

Bosma, Niels, Kent Jones, ErkkoAutio and Jonathan Levie. (2008). GEM 2007 Executive Report, Babson Park, MA: Babson College, London Business School, and GERA.

Brewer, T. D., Cinner, J. E., Fisher, R., Green, A., \& Wilson, S. K. (2012). Market access, population density, and socioeconomic development explain diversity and functional group biomass of coral reef fish assemblages. Global Environmental Change, 22(2), 399-406. doi:10.1016/j.gloenvcha.2012.01.006

Bruton, G. D., Ketchen, D. J. and Ireland, R. D. (2013). Entrepreneurship as a solution to poverty, Journal of Business Venturing, 28(6), 683-689. 
Cassar, G., \& Friedman, H. (2009). Does self-efficacy affect entrepreneurial investment?. Strategic Entrepreneurship Journal, 3(3), 241-260.

Clemens, B. (2006). Economic incentives and small firms: Does it pay to be green? Journal of Business Research, 59(4), 492-500.

Conroy, D. E. (2004). The unique psychological meanings of multidimensional fears of failing. Journal of Sport \& Exercise Psychology, 26, 484-491.

Corbett, A. C. (2007). Learning asymmetries and the discovery of entrepreneurial opportunities. Journal of business venturing, 22(1), 97-118.

Cruz, L.D., Suprapti, S., Yasa, K. (2015). Aplikasi Theory of Planned Behavior DalamMembangkitkanNiatBerwirausahaBagiMahasiswaFakultasEkonomiUnpaz, Dili Timor Leste. E-JurnalEkonomidanBisnisUniversitasUdayana. 4(12), 895-920.

Davidsson, P. (1995). Culture, structure and regional levels of entrepreneurship. Entrepreneurship and Regional Development, 7, 41-52.

Davidsson, P., \&Wiklund, J. (1997). Values, beliefs and regional variations in new firm formation rates. Journal of Economic Psychology, 18,179-199.

Douglas, Evan and Dean Shepard. (2002). Self-Employment as a career choice: Attitudes, EI and utility maximization, Entrepreneurship Theory and Practice, 26(3), 81-90.

European Commission. (2010). Europe 2020. A european strategy for smart, sustainable and inclusive growth. Available at: http:/ /ec.europa.eu/eu2020/pdf/COMPLET\%20EN\%20BARROSO\%20\%20\%20 007\%20$\% 20$ Europe $\% 202020 \% 20-\% 20$ EN\%20version.pdf (accessed 20 October 2014).

Fisher, R., Maritz, A., \& Lobo, A. (2014). Evaluating entrepreneurs' perception of success. International Journal of Entrepreneurial Behavior \& Research, 20(5), 478-492. https://doi.org/10.1108/ijebr-1020130157.

Gimeno, J., Folta, T. B., Cooper, A. C., \& Woo, C. Y. (1997). Survival of the fittest? Entrepreneurial human capital and the persistence of underperforming firms. Administrative Science Quarterly, 42(4), 750-783.

Gorgievski, M. J., Ascalon, E. M., \& Stephan, U. (2011). Small business Owners' success criteria, a values approach to personal differences. Journal of Small Business Management, 49(2), 207-232. https://doi. org/10.1111/j.1540-627X.2011.00322.x.

Hamidi, D., Wennberg, K., \& Berglund, H. (2008). Creativity in entrepreneurship education. Journal of Small Business and Enterprise Development, 15(2), 304-20.

Hayton, C. James, Gerard George and Shaker A. Zahra, (2002), "National Culture and Entrepreneurship: A Review of Behavioral Research", Entrepreneurship Theory and Practice, 26(4), $33-52$.

Henseler, J., and Sarstedt, M. (2013). Goodness-of-Fit Indices for Partial Least Squares Path Modeling, Computational Statistics, 28(2), 565-580.

Hosseini, M., Dadfar, H. \&Brege, S. (2018), Firm-level entrepreneurship and international performance: A simultaneous examination of orientation and action, Journal of International Entrepreneurship. 6(8) 1-22. https://doi.org/10.1007/s10843-018-0235-6

Kelley, Donna, Niels Bosma and Jose Ernesto Amorós. (2011). GEM, 2010 Global Report, Babson Park, MA and Santiago, Chile: Babson College and Universidad del Desarrollo.

Kolvereid, Lars and EspenIsaksen. (2006). "New business start-up and subsequent entry into selfemployment", Journal of Business Venturing, 21(6), 866-885. https://doi.org/10.1016/j.jbusvent.2005.06.008

Krueger, F. Norris, Michael D. Reilly and Alan I. Carsrud. (2000). Competing Models of EI, Journal of Business Venturing, 15(5-6), 411-432. https://doi. org/10.1016/S0883-9026(98)00033-0

Kuratko, D. F. (2005). The emergence of entrepreneurship education: Development, trends, and challenges. Entrepreneurship: Theory and Practice, 29, 577-597.

Lado, A. A., \&Vozikis, G. S. (1996). Transfer of technology to promote entrepreneurship in developing countries: An integration and proposed framework. Entrepreneurship Theory and Practice, 21, 55. 
Lee, Soo Hoon and PohKam Wong. (2004). An exploratory study of technopreneurial intentions: a career anchor perspective, Journal of Business Venturing, 19(1), 7-28.

https://doi.org/10.1016/S0883-9026(02)00112-X

Lent, R. W. \& Hackett, G. (1987). Career self-efficacy: Empirical status and future directions Journal of Vocational Behavior, 30, 347-382.

Linan, Francisco and Yi-Wen Chen. (2009). Development and cross-cultural application of a specific instrument to measure EI, Entrepreneurship Theory and Practice, 33(3), 593-617. https://doi.org/10.1111/j.1540-6520.2009.00318.x

Lumpkin, G. T., \&Dess, G. G. (2001). Linking two dimensions of entrepreneurial orientation to firm performance: The moderating role of environment and industry life cycle. Journal of Business Venturing, 16(5), 429-451. https://doi.org/10.1016/S0883-9026(00)00048-3.

Martinez, M., Yang, T. \& Aldrich, H. (2011). Entrepreneurship as an evolutionary process: Research progress and challenges. Entrepreneurship Research Journal, 1(1), 14-25. doi:10.2202/2157-5665.1009.

Parker, S.C., \& Robson, M.T. (2004). Explaining international variations in self-employment: Evidence from a panel of OECD countries. Southern Economic Journal, 71(2), 287-301.

Reijonen, H., \&Komppula, R. (2007). Perception of success and its effect on small firm performance. Journal of Small Business and Enterprise Development, 14(4), 689-701. https://doi.org/10.1108 $\angle 14626000710832776$.

Reynolds, P. D. (1987). New firms - societal contribution versus survival potential. Journal of Business Venturing, 2(3), 231-246. https://doi.org/10.1016/0883-9026(87)90011-5.

Reynolds, P., Bosma, N., Autio, E., Hunt, S., De Bono, N., Servais, I., et al. (2005). Global entrepreneurship monitor: Data collection design and implementation 1998-2003. Small Business Economics, 24(3) 205-231.

Robinson, P. B., Stimpson, D. V., Huefner, J. C., \& Hunt, H. K. (1991). An attitude approach to the prediction of entrepreneurship. Entrepreneurship Theory and Practice, 13-31.

Schumpeter, J. A. (1990). The theory of economic development: an inquiry into profits, capital, credit, interest and the business cycle. In M. Casson (Ed.), Entrepreneurship (pp. 105-134). Edward Elgar Pub. Ltd., Hants.

Shapero, Albert and Lisa Sokol. (1982) "Social dimension of entrepreneurship" in C.A. Kent, D.L. Sexton, K.H. Vasper, eds., Encyclopedia of Entrepreneurship, pp. 72-90, Englewood Cliffs, NJ: Prentice Hall.

Shapero, Albert. (1984). "The entrepreneurial event" in C.A. Kent, ed., The Environment for Entrepreneurship, 21-40, Lexington, MA: Lexington Books.

Shinnar, S. Rachel, Olivier Giacomin and Frank Janssen. (2012). "Entrepreneurial perceptions and intentions: The role of gender and culture", Entrepreneurship Theory andPractice, 36(3), pp. 465-493. https://doi.org/10.1111/j.1540-6520.2012.00509.x

Stam, E., Hartog, C., Van Stel, A., \&Thurik, R. (2011). Ambitious entrepreneurship, highgrowth firms and macroeconomic growth. In M. Minniti (Ed.), The dynamics of entrepreneurship: Evidence from the global entrepreneurship monitor data (pp. 231250). Oxford, UK: Oxford University Press.

Stam, E., Suddle, K., Hessels, S. J. A., \& Van Stel, A. (2009). High-growth entrepreneurs, public policies and economic growth. In J. Leitao\& R. Baptista (Eds.), Public policies for fostering entrepreneurship: A European perspective (Vol. 22, pp. 91110). International Studies in Entrepreneurship. New York, NY: Springer Science.

Wach, D., Stephan, U., \&Gorgievski, M. J. (2016). More than money: Developing an integrative multifactorial measure of entrepreneurial success. International Small Business Journal, 34(8), 10981121. https://doi.org/10.1177/0266242615608469.

Wedayanti, N. P., danGiantari, I. (2016). PeranPendidikanKewirausahaanDalamMemediasiPengaruh Norma SubyektifTerhadapNiatBerwirausaha.E-JumalManajemenUniversitasUdayana. 5(1), 533-560. 